\title{
Coralline algal rhodoliths enhance larval settlement and early growth of the Pacific calico scallop Argopecten ventricosus
}

\author{
Diana L. Steller ${ }^{1, *}$, Carlos Cáceres-Martínez ${ }^{2}$ \\ ${ }^{1}$ Moss Landing Marine Laboratories, 8272 Moss Landing Rd., Moss Landing, California 95039, USA \\ ${ }^{2}$ Departamento de Ingeniería en Pesquerías, Universidad Autónoma de Baja California Sur, Apartado postal 19-B, La Paz, \\ Baja California Sur, México
}

\begin{abstract}
The features of heterogeneous rhodolith beds (maerl) that contribute to their role as nursery habitats in coastal ecosystems are poorly understood. Rhodoliths are branched, unattached coralline algae that form complex benthic substrates and support diverse communities worldwide. Pacific calico scallops Argopecten ventricosus = circularis (Sowerby II, 1842) occur in high densities in rhodolith beds in the Gulf of California, México. In this study, we found that Lithophyllum margaritae rhodoliths enhanced larval scallop settlement and early post-settlement growth, and examined the settlement cues responsible. In both field and laboratory experiments, larval settlement was significantly higher on (1) rhodolith derived vs. non-coralline sedimentary substrates, (2) living vs. nonliving coralline surfaces, and (3) substrates with higher (whole, branching rhodoliths) vs. lower (rhodolith fragments or sediment) structural complexity. In the field, larval settlement (mean $\pm \mathrm{SE}$ ) onto rhodoliths was 30 to 35 times higher on live rhodoliths $\left(55.0 \pm 13.4\right.$ and $84.4 \pm 8.8$ larvae $\left.\mathrm{cm}^{-2}\right)$ than on non-carbonate sediment $\left(1.8 \pm 0.8\right.$ and $2.4 \pm 0.9$ larvae $\left.\mathrm{cm}^{-2}\right)$ relative to the surrounding rhodolith or sand habitat, respectively. In a laboratory preference experiment, when comparing live vs. dead coralline surfaces respectively, settlement density was 3.3 times greater (55.8 \pm 14.6 vs. $17.0 \pm$ 4.9 larvae $\left.\mathrm{cm}^{-2}\right)$ on whole rhodoliths and 7 times greater $\left(24.2 \pm 4.7\right.$ vs. $3.4 \pm 1.3$ larvae $\left.\mathrm{cm}^{-2}\right)$ on fragmented rhodoliths. The strong cueing to live coralline surfaces may have resulted from live coralline algal surfaces or surface biofilms. Growth, presented as post-settlement size, was significantly greater in scallops that settled onto whole vs. fragmented rhodolith substrates for both live $(246.6 \pm 1.9 \mathrm{vs}$. $238.9 \pm 4.4 \mu \mathrm{m})$ and dead $(244.2 \pm 2.8$ vs. $234.7 \pm 5.6 \mu \mathrm{m})$ coralline surfaces. The structural and coralline cues provided by live, intact rhodoliths and their large-grained sediments contribute to the importance of rhodolith beds as nursery habitats by increasing both scallop settlement and postsettlement growth. Protection of living rhodolith habitats can enhance scallop and other invertebrate populations as well as the sustainability of scallop fisheries by enhancing early life stages.
\end{abstract}

KEY WORDS: Argopecten ventricosus - Coralline $\cdot$ Rhodolith · Scallop $\cdot$ Larval settlement cues · Lithophyllum margaritae · Maerl · Bahía Concepción

\section{INTRODUCTION}

Understanding the link between the planktonic and benthic life history phases of marine organisms is a major focus in marine ecology (Caley et al. 1996, Morgan 2001). For marine invertebrates with complex life histories, the process of settlement and metamorphosis is a critical and typically irreversible transition from planktonic to benthic life-history phases. An increasing number of studies have shown that the settlement process is not random (Crisp 1976, Hadfield 1986, Young 1990), that variation can be an important factor determining the abundance and distribution of organisms (Thorson 1966, Underwood \& Denley 1984, Con- 
nell 1985, Raimondi 1990), and thereby strongly influence population and community-level processes (Rodriguez et al. 1993, Connolly \& Roughgarden 1999). While hydrodynamic processes are known to strongly influence the delivery of larvae to suitable substrates (Butman et al. 1988, Abelson \& Denny 1997), behavior in response to cues is also important in determining settlement patterns (Crisp 1974, Hadfield 1986, Raimondi \& Morse 2000).

Settlement cues, often required for metamorphosis of marine invertebrate larvae (Morse \& Morse 1984, Pearce \& Scheibling 1990), are thought to be indicative of environmental features that enhance survivorship (e.g. habitat, refuge, food or conspecifics). Physical cues include hydrodynamics (Crisp 1955), light (Crisp \& Ritz 1973), depth (Knight-Jones \& Morgan 1966), surface structural complexity (Harvey et al. 1993, Pearce \& Bourget 1996), disturbance events (Woodin et al. 1995) and surface chemistry (Hay 1996, Steinberg \& de Nys 2002). Biological cues include presence of conspecifics (Keough 1998) and bacterial or bioorganic films (Maki et al. 1989, Keough \& Raimondi 1995, Huggett et al. 2006). In addition, physical and biological cues can act synergistically (Crisp \& Meadows 1963, Gee 1965, Le Tourneux \& Bourget 1988). Few studies have been conducted in the field to understand in situ larval responses (Keough \& Raimondi 1995) and how the distribution or magnitude of various cues might influence larval settlement (Underwood \& Keough 2000).

Complex seaweed surfaces, such as those found in coralline algae, provide combinations of physical and biological cues that can influence settlement in a range of invertebrates (Walters et al. 1996, Steinberg \& de Nys 2002). Species of geniculate and non-geniculate (crustose) forms of coralline red algae occur in most coastal environments (Bosence 1983). A variety of invertebrate larvae are induced to settle on coralline algae by the physical features of the complex surfaces found on attached coralline algae (Daume et al. 1999a), or by the surface chemistry of algal pigments or associated epibionts (Morse 1992, Huggett et al. 2006); therefore, coralline algal distribution can have a strong influence on the distribution of some marine invertebrates (Raimondi \& Morse 2000). Understanding the importance of particular coralline surface cues to larval settlement enhances the understanding of the ecological role corallines play in the distribution of some marine species.

Unlike attached corallines, rhodoliths (also known as maerl) are individual, branching, unattached, mobile forms of crustose coralline algae (Fig. 1) that collectively form large heterogeneous beds of biogenic substrates on sedimentary benthos worldwide (Foster 2001). Rhodolith beds support a diverse and abundant

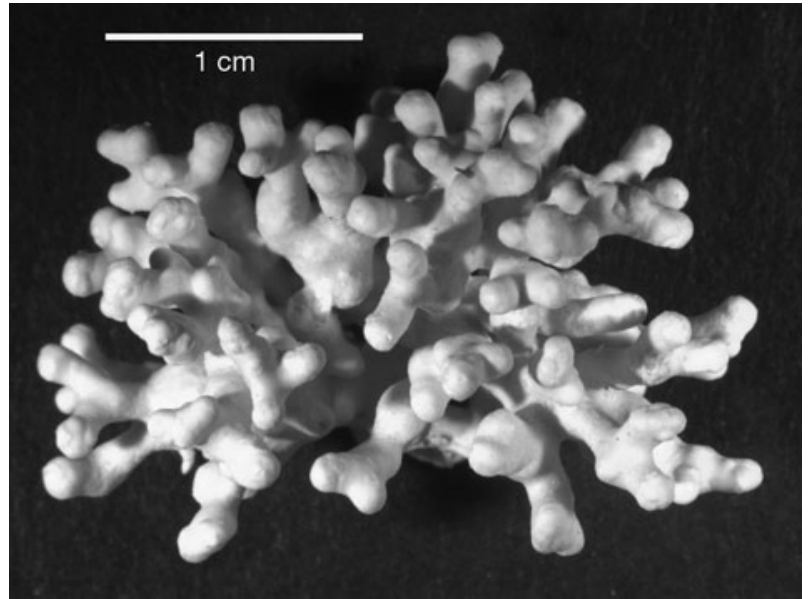

Fig. 1. Lithophyllum margaritae. Fruticose branching rhodolith used in all experiments, collected at a 6-8 $\mathrm{m}$ depth at the El Requesón rhodolith bed, Bahía Concepción

assemblage of soft and hard bottom organisms (Keegan 1974, Bosence 1979, Steller et al. 2003), including abundant juvenile stages of some invertebrates (Kamenos et al. 2004a, D. Steller pers obs.). However, few studies have examined the processes driving these substrate-species relationships. Scallops are found in rhodolith beds and commercial harvesting of Atlantic species has lead to the destruction, and subsequently protection, of numerous European maerl beds due to their fragile nature (Hall-Spencer \& Moore 2000b). The trawling for bivalves reduces epifaunal and infaunal diversity through the loss of habitat complexity and through rhodolith thallus fragmentation resulting from the large-scale homogenization of the benthos (HallSpencer 1999). Studies have demonstrated that maintaining a high cover of whole, branching rhodolith thalli is essential to the maintenance of high biodiversity (Grall \& Glemarec 1997, Grall et al. 2006). Increasing anthropogenic disturbances have motivated recent conservation efforts focused on the protection of fragile rhodolith habitats combined with addressing the need to more clearly understand the ecological role of this benthic habitat in species relationships.

Scallop life histories are fairly well understood and the association of adult populations with rhodoliths (Hily et al. 1992, Hall-Spencer \& Moore 2000b) offers a model species with which to examine the ecological interactions and possible benefits from an association with rhodoliths at different life stages. This may provide insight into the high abundance and diversity of other adult species associated with this habitat. High juvenile scallop densities ( $\geq 18$ to $35 \mathrm{~mm}$ ) in rhodolith beds (Kamenos et al. 2004a) have been associated with greater selection, attachment and growth and indicate that rhodolith habitats are used as nursery grounds or 
refuge for some species (Kamenos et al. 2004b,c). Additionally, association with rhodolith beds has been shown to confer a substrate-mediated benefit to adult scallops as a refuge from predators (Kamenos et al. 2006). Less, however, is known about rhodolith substrate relationships with larval stages. One study measured high post-larval scallop recruitment to experimental spat collectors over maerl substrates in the Georges Banks, leading to the suggestion that rhodolith beds may serve as larval 'nursery grounds' (Thouzeau 1991). The reduction of structural complexity and killing of live coralline surfaces of rhodoliths due to anthropogenic disturbances motivates the need to examine the role of rhodolith and rhodolith derived substrates in the induction of larval settlement and subsequent growth of newly settled individuals.

Scallop fisheries are important in bays in the Gulf of California and along the Pacific coast of Baja California, Mexico (Felix Pico 1991). A primary fisheries species is the Pacific calico or catarina scallop Argopecten ventricosus = circularis (Sowerby II, 1842), a motile, soft bottom species that reaches market size within a year. Extreme population declines due to multiple factors have resulted in efforts in Mexico to increase natural populations through aquaculture and enhanced field recruitment (Ruiz-Martinez \& Cáceras-Martínez 1991, Felix-Pico et al. 1997, Maeda-Martinez et al. 1997). Similar population declines in Panamanian fisheries of the same species have been attributed to a lack of suitable habitat for early life stages, predation and changes in oceanographic conditions (Medina et al. 2007). For many scallop species, larval settlement occurs on a variety of substrates, but appears to be enhanced by increased substrate complexity and the degree of bio-fouling (Brand et al. 1980, Pearce \& Bourget 1996, Harvey \& Bourget 1997). The importance of heterogeneous substrates to recruitment along with the co-occurrence of large populations of scallops and rhodoliths (Steller et al. 2003) suggests the possibility of strong cuing of $A$. ventricosus larvae to rhodolith surfaces for settlement.

Using Argopecten ventricosus as a model, we examine the importance of surface cues provided by 2 common benthic substrates in the Gulf of California, the rhodolith Lithophyllum margaritae and non-carbonate sediment, in the induction of larval scallop settlement and subsequent early post-settlement growth. We hypothesize that (1) settlement of scallop larvae will be enhanced on rhodolith derived substrates with live coralline surfaces and the high structural complexity of intact branching relative to dead or non-coralline surfaces with fragmented brancehes or low structural complexity, and (2) larvae selecting substrates with optimal surface cues will gain a benefit of enhanced post-settlement growth. Understanding the relative importance of rhodolith characteristics in the establishment and enhancement of scallop populations provides a mechanism by which rhodoliths may enhance populations of other species. This information will help identify rhodolith habitat features important to populations of associated species and features that need protection from anthropogenic threats.

\section{MATERIALS AND METHODS}

Location. Benthic substrate collections and a field experiment were conducted in Bahía Concepción (45 km in length, $60 \mathrm{~m}$ in maximum depth) located in the west central Gulf of California in Baja California Sur (BCS), Mexico (26 $\left.38^{\prime} 57^{\prime \prime} \mathrm{N}, 111^{\circ} 49^{\prime} 82^{\prime \prime} \mathrm{W}\right)$. The soft bottom in this bay is dominated by fine grain, noncarbonate volcanic sediments and interspersed with large grain, carbonate sediments derived from the rhodolith beds distributed along the western shore (Steller \& Foster 1995). Rhodolith beds in the Gulf of California and Bahía Concepción are dominated by Lithophyllum margaritae (Fig. 1), a morphologically variable species (Riosmena-Rodríguez et al. 1999). Historically, the bay has been a major area of scallop production, but the fishery collapsed in the early 1990's and was closed in 1993. Subsequently, intensive efforts have been made to understand the recruitment and growth cycles of the scallops, and to re-establish the fishery (ChavezVillalba \& Cáceres-Martínez 1992, Villalejo-Fuerte 1993, Felix-Pico et al. 1997). Annual surface water temperatures in Bahía Concepción range from $\leq 18$ to $30^{\circ} \mathrm{C}$. Scallop recruitment generally occurs between January and March, coincident with the spring increase in water temperature from winter temperatures, from $\leq 18^{\circ} \mathrm{C}$ to temperatures between 21 to $22^{\circ} \mathrm{C}$ (Villalejo-Fuerte 1993). Adult scallop densities in rhodolith beds were previously highest in the deeper $(11 \mathrm{~m})$ portions of a rhodolith bed that spanned a depth from 4 to $11 \mathrm{~m}$ (Steller et al. 2003). The field experiment in this study was conducted in February 2000 when the probability of scallop settlement was optimal.

Substrate preparation. Scallop settlement preferences were measured across benthic substrate types commonly found in and around rhodolith beds using 3 different experiments and with a focus on 2 primary cues (Table 1). The 5 substrate types varied in the level of live coralline surface cue (present/absent) and structural complexity (high/low): (1) live fruticose (branching) Lithophyllum margaritae rhodoliths with live coralline surface present and high structural complexity with intact branching (live rhodolith, LR); (2) dead L. margaritae rhodoliths with live coralline surface absent and high structural complexity with intact branching (dead rhodolith, DR); (3) live rhodolith fragments with live 
Table 1. Lithophyllum margaritae. Experimental substrate treatments by code, live coralline cue (presence vs. absence), level of structural complexity (high vs. low) and experiment. x: substrate used in a particular experiment. Pref: preference

\begin{tabular}{|c|c|c|c|c|c|c|c|}
\hline Substrate & $\begin{array}{l}\text { Stylised } \\
\text { illustration }\end{array}$ & $\begin{array}{l}\text { Treatment } \\
\text { code }\end{array}$ & $\begin{array}{l}\text { Live } \\
\text { coralline cue }\end{array}$ & $\begin{array}{c}\text { Structural } \\
\text { complexity }\end{array}$ & Field pref. & $\begin{array}{c}\text { Experiment } \\
\text { Lab. pref. }\end{array}$ & Lab. growth \\
\hline Live rhodolith & $\Omega_{\pi}^{\infty}$ & LR & present & high & $\mathrm{x}$ & $\mathrm{x}$ & $\mathrm{x}$ \\
\hline Dead rhodolith & हñ్ & DR & absent & high & $\mathrm{x}$ & $\mathrm{x}$ & $\mathrm{x}$ \\
\hline Live rhodolith fragments & & LF & present & low & & $\mathrm{x}$ & $\mathrm{x}$ \\
\hline Dead rhodolith fragments & & $\mathrm{DF}$ & absent & low & $\mathrm{x}$ & $\mathrm{x}$ & $\mathrm{x}$ \\
\hline Non-carbonate fine sediment & & FS & absent & low & $\mathrm{x}$ & $\mathrm{x}$ & \\
\hline
\end{tabular}

coralline surface present and low structural complexity (live rhodolith fragments, LF); (4) dead rhodolith fragments (2 to $4 \mathrm{~mm}$ ) with live coralline surface absent and low structural complexity (dead rhodolith fragments, $\mathrm{DF})$; and (5) fine grain $(<0.5 \mathrm{~mm})$, non-carbonate sediment with live coralline surface absent and low structural complexity (fine sediment, FS).

Substrate treatment preparation was similar among experiments but experimental setup varied relative to the question and logistics. In all experiments, live and dead whole rhodolith treatments and live fragment treatments (LR, DR and LF) were derived from living Lithophyllum margaritae rhodoliths (1 to $2 \mathrm{~cm}$ diameter) with intact branches that were collected from a depth of $8 \mathrm{~m}$ at Manto El Requesón, Bahía Concepción. Associated macroflora and fauna were removed and rhodoliths were lightly scrubbed with a soft plastic brush. Dead coralline rhodolith fragments (DF) were obtained from either (1) a sand flat $20 \mathrm{~m}$ outside of the rhodolith bed at 6 to $8 \mathrm{~m}$ depth, used in the field and laboratory preference experiments; or (2) from breaking apart whole, dead rhodoliths for the growth experiment. Fine grain, non-carbonate, volcanic sediment (FS, $<0.5 \mathrm{~mm}$ diameter) was collected $200 \mathrm{~m}$ outside of the rhodolith bed at $8 \mathrm{~m}$ depth. Fine sediment had the lowest structural complexity of the treatments and lacked any known coralline cue. Material for all treatments void of live surface chemistry (DR, DF, FS) was boiled vigorously for $20 \mathrm{~min}$ in deionized water to denature and disrupt surface proteins, pigments and associated organisms. Substrates were either dabbed dry (live material) or air dried (dead or non-living material) prior to preparation into experimental units and subsequently soaked in aerated, filtered seawater for $>24 \mathrm{~h}$ prior to the experiment.
Effects of substrate on settlement. Field experiment: The field preference experiment was conducted in February 2000 to compare patterns of larval scallop settlement on 4 common benthic substrates relative to the surrounding sediments in 2 locations: a rhodolith bed and a sand flat. The substrate treatments included were those typically found in and around a rhodolith bed (LR, DR, DF, FS; Table 1). The underlying benthic substrate varied with location thus allowing for an examination of the settlement signal of a substrate treatment relative to surrounding dominant benthic cover. For logistical reasons and ease of outplanting, 6 experimental panels were prepared containing a replicate of each of the 4 substrates tested. The panels consisted of clear plastic rectangles $(17 \times 5 \mathrm{~cm})$ divided longitudinally into 4 equal squares. Each square contained a central $3 \times 3 \mathrm{~cm}$ region (separated by a $1 \mathrm{~cm}$ buffer zone) onto which randomly assigned material for 1 of the 4 treatments was attached with cyanocrylate glue (Krazy Glue). The effect of glue on scallop settlement was tested in a laboratory experiment and was non-significant (D. Steller unpubl. data), as was previously reported (Miron et al. 1996).

Six experimental panels were deployed into each of the 2 locations supporting adult Argopecten ventricosus populations: the El Requesón rhodolith bed and a sand flat $\sim 100 \mathrm{~m}$ outside of the bed. In an $\sim 10 \mathrm{~m}^{2}$ area in each location, replicate panels were moored $\sim 2 \mathrm{~m}$ apart onto the benthos with stakes at a depth of $10 \mathrm{~m}$. To verify that scallop settlement had occurred prior to ending the experiment, one panel from each location was collected after $4 \mathrm{~d}$ and examined; however, data were not utilized in the final analysis. Experimental panels were thus deployed for $5 \mathrm{~d}$ due to logistics and to allow for settlement, then collected and transported 
to the surface where panels were immediately cut up into respective treatment squares and preserved in $80 \%$ EtOH. Attached larvae do not release from the substrate when fixed, thus allowing for post-collection density estimates. The density of settled scallop larvae on the surface of a $1 \mathrm{~cm}^{2}$ portion of each replicate was subsequently determined through a dissecting microscope $(5 \times$ power $)$ on the day of collection.

Laboratory experiments: Laboratory experiments were conducted with cultured Argopecten ventricosus larvae at the Universidad Autónoma de Baja California Sur (UABCS) aquaculture facility at Pichilingue, La Paz, México during February 1998 and 1999: a time which coincides with the regional spawning and recruitment period of wild scallops (Felix-Pico et al. 1997). Adult scallops were collected from Bahía Magdalena, BCS and fed with high concentrations of diatoms to condition them for spawning under lab conditions. In each year, 12 scallops were induced to spawn and the resulting larvae were divided equally between 2 aerated 15001 fiberglass tanks filled with 5001 of filtered seawater for $15 \mathrm{~d}$. Feeding stage larvae were fed the microalgae Isochrysis spp. and Chaetoceros gracilis on a daily basis at concentrations of 30000 cells $\mathrm{ml}^{-1} \mathrm{~d}^{-1}$, from Day 0 to $7 ; 60000$ cells $\mathrm{ml}^{-1} \mathrm{~d}^{-1}$ from Day 8 to 12 , and 80000 cells $\mathrm{ml}^{-1} \mathrm{~d}^{-1}$ from Day 13 until the conclusion of the experiments. Water temperature for cultures and experiments ranged from 20.5 to $22.0^{\circ} \mathrm{C}$ in 1998 and 19.0 to $21.5^{\circ} \mathrm{C}$ in 1999 , reflecting the ambient seawater temperatures. During the early larval development period, the water was drained and changed every $2 d$, at which time all larvae were concentrated, counted and measured. Experiments were initiated when $\sim 70 \%$ of the larvae were competent to settle $(\sim 15 \mathrm{~d})$, corresponding to a larval maximum shell length of 240 to $250 \mu \mathrm{m}$. One batch of larvae was used for each laboratory experiment as they were conducted in different years.

The laboratory preference experiment was conducted to test for the strength of settlement cues under controlled conditions and using a wider range of substrates than tested in the field experiment: 5 substrates commonly found in and around rhodolith beds (Table 1). Settlement patterns associated with coralline and structural cues were more thoroughly examined with the additional treatment consisting of LF, allowing for the examination of a live coralline surface under low structural complexity. Rhodoliths and sediments used in the experiment were collected from Bahía Concepción in the same manner as in the field preference experiment and transported and prepared in the Pichilingue laboratory.

Prepared in the same manner as the field panels, 5 experimental panels were constructed, except that these were longer $(25 \times 5 \mathrm{~cm})$ in order to accommodate the treatment (LF), divided longitudinally into 5 equal squares, and contained a replicate of each of the 5 substrate treatments in a $3 \times 3 \mathrm{~cm}$ area. Treatments were randomly assigned to squares, each square separated from adjacent treatments by a $1 \mathrm{~cm}$ buffer zone. After preparing the larvae in 1999, the treatment panels were suspended in a single aerated tank containing $500 \mathrm{l}$ of filtered seawater with competent scallop larvae at a density of 5 larvae $\mathrm{ml}^{-1}$. Water was continuously moving due to aeration. After $3 \mathrm{~d}$, panels were removed and examined to determine if settlement had occurred. Settlement was observed on all substrates; thus, the experiment was ended, treatment squares separated, fixed in $80 \% \mathrm{EtOH}$ and the number of settled larvae $\mathrm{cm}^{-2}$ immediately counted on each treatment surface using a dissecting microscope $(5 \times$ power $)$.

Effects of substrate on post-settlement growth. A laboratory growth experiment was conducted to assess patterns of early post-settlement growth relative to the surface cues of rhodolith-derived substrates. An orthogonal design was used to isolate the effects of live coralline surface presence or absence and of high or low structural complexity on both settlement and early post-settlement growth, reported as post-settlement size. Rhodoliths were collected from Bahía Concepción and used to prepare 4 treatments: LR, DR, LF, and DF. All rhodoliths were assessed for wet weight and branching density, determined as number of branch tips within 5 randomly placed $1 \mathrm{~cm}^{2}$ quadrats on the rhodolith surface. A standardized amount $(1.2 \mathrm{~g})$ of whole rhodolith material of similar size with similar branching density (9 branches $\mathrm{cm}^{-2}$ ) was used in each replicate. Fragmented treatments were produced by breaking branches of intact rhodoliths into fragments of $<5 \mathrm{~mm}$. All rhodolith treatment material was attached to separate, individual $5 \mathrm{~cm}$ diameter petri dishes with cyanocrylate glue. Four PVC shelves, each containing 4 petri dishes with a replicate of each treatment in randomly assigned locations, were suspended in the tank. In February 1998 a batch of scallop larvae was reared as described above. When $70 \%$ of the larvae were competent, they were placed in $1500 \mathrm{l}$ aerated tanks holding $500 \mathrm{l}$ of water at a concentration of 4 larvae $\mathrm{ml}^{-1}$. Experimental duration was $3 \mathrm{~d}$ to allow for settlement and growth.

At the end of the experiment, all settled larvae were removed from treatment surfaces using a 5\% bleach solution in seawater rinse, concentrated using a $240 \mu \mathrm{m}$ sieve and preserved in $80 \%$ EtOH. All larvae were examined for the presence of a post-settlement growth crest extending beyond the larval shell, which reflects a change in shell morphology and signifies the transition between a swimming veliger (velum present) and a crawling post-larva (velum absent) (Uriarte et al. 2002). Only larvae with a growth crest present were used to 
Table 2. Argopecten ventricosus. Settlement preferences of larvae in the field. ANOVA results comparing larval settlement (ln settlers $\mathrm{cm}^{-2}$ ) between locations (rhodolith bed and sand flat) and among 4 substrate types with panel nested within location.

Values in italics = results of planned general contrast tests comparing substrate types. See Table 1 for substrate codes

\begin{tabular}{|c|c|c|c|c|c|}
\hline Source & SS & df & MS & $F$ & $\mathrm{p}$ \\
\hline Location & 3.641 & 1 & 3.641 & 17.936 & 0.005 \\
\hline Substrate & 54.765 & 3 & 18.255 & 98.566 & $<0.001$ \\
\hline Coralline cue: $L R$ (present) vs. DR, DF, FS (absent) & 11.34 & 1 & 11.344 & 61.25 & $<0.001$ \\
\hline Structure: LR, DR (high) vs. DF, FS (low) & 28.512 & 1 & 28.512 & 153.9 & $<0.001$ \\
\hline Location $\times$ Substrate & 0.846 & 3 & 0.282 & 1.523 & 0.243 \\
\hline Panel (Location) & 1.221 & 6 & 0.203 & 1.099 & 0.401 \\
\hline Error & 3.334 & 18 & 0.185 & & \\
\hline
\end{tabular}

compare treatment-related differences in total settlement and post-settlement size between treatments. Post-settlement size, the maximum shell depth (larval shell + new growth, in $\mu \mathrm{m})$, was measured from 11 to 50 (average $=35$ ) individuals per replicate.

Data analysis. For the field preference experiment, differences in settlement density (ln settlers $\mathrm{cm}^{-2}$ ) among substrate types and between locations (rhodolith bed vs. sand flat) were examined with a 3way ANOVA using panel as a nested factor within location. The importance of particular structural and coralline surface cues to larval settlement were assessed via planned general contrast comparisons among the 4 substrate treatments: (1) presence vs. absence of live coralline surface (LR vs. DR, DF, FS), (2) high vs. low structural complexity (LR, DR vs. DF, FS).

In the laboratory preference experiment, differences in larval settlement among 5 substrate treatments (ln [settlers $+1 \mathrm{~cm}^{-2}$ ) were examined with a 1-way ANOVA comparing substrates. The importance of particular cues on settlement density was assessed via planned general contrast comparisons: (1) presence vs. absence of living coralline tissue (LR, LF vs. DR, DF, FS), (2) high vs. low structural complexity (LR, DR vs. LF, DF, FS).

In the laboratory growth experiment, the effects of live coralline surface cue (presence vs. absence) and structural complexity (high vs. low) on ln (total no. settlers) and ln (post-settlement size) were examined with 2-way ANOVAs. A power analysis was used to determine if sample size was sufficient to capture non-significant results. Data in all analyses were initially evaluated for normality and homoscedasticity using a Cochran's test, transformed if necessary and re-tested.

\section{RESULTS}

\section{Effects of substrate on settlement}

Field experiment. In the field preference experiment, settlement of wild scallop larvae occurred on all 4 substrate types (LR, DR, DF, FS) in both locations (rhodolith bed, sand flat) after 5 d (Fig. 2). Both location and substrate type had significant effects on settlement density (Table 2) and density was higher on all substrates deployed on the sand flat relative to those on the rhodolith bed, with the exception of the fine sediment, on which densities were similar. Scallop densities (mean $\pm \mathrm{SE}$ ) varied across substrate types and were 30 to 35 times higher on live rhodoliths (55.0 \pm 13.4 and $84.4 \pm 8.8$ larvae $\mathrm{cm}^{-2}$ ) than on a non-carbonate sediment $\left(1.8 \pm 0.8\right.$ and $2.4 \pm 0.9$ larvae $\left.\mathrm{cm}^{-2}\right)$ relative to the surrounding rhodolith or sand habitat. On the sand flat, settlement decreased with the reduction in structural complexity, with no clear effect of the live coralline cue. However, in the rhodolith bed, settlement was greatest in the presence of both live coralline and high structural complexity and declined with decreasing structural complexity in treatments where the live coralline cue was absent. Overall, field settlement was significantly enhanced in the presence of both a live coralline cue and higher structural complexity (post hoc contrast tests; Table 2).

Laboratory experiments. In the laboratory preference experiment, settlement of cultured scallop larvae

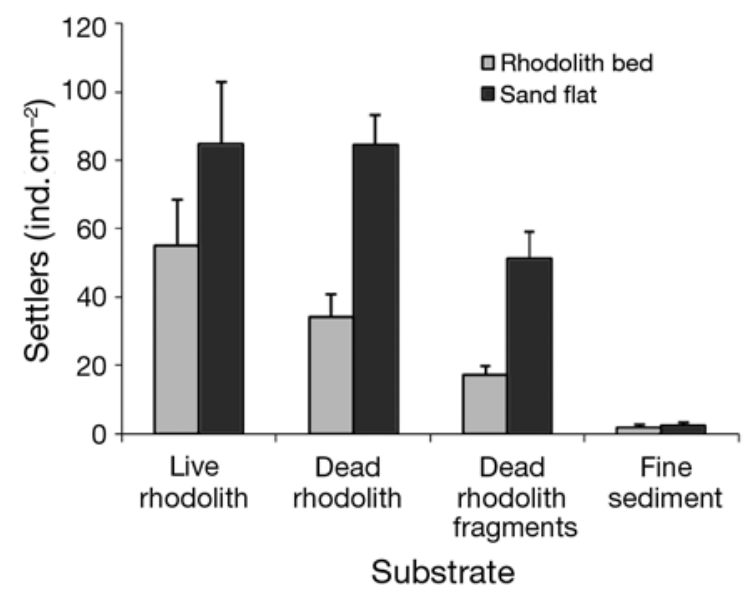

Fig. 2. Argopecten ventricosus. Field settlement preferences of larval scallops relative to substrate treatments (Lithophyllum margaritae whole and fragmented rhodolith substrates) and location (rhodolith bed vs. sand flat) in Bahía Concepción. $\mathrm{n}=5$; error bars $=\mathrm{SE}$ 
Table 3. Argopecten ventricosus. Settlement preferences of larvae in the laboratory. One-way fixed ANOVA results comparing settlement (ln [settlers $+1 \mathrm{~cm}^{-2}$ ]) among 5 substrate types. Values in italics $=$ results of planned general contrast tests comparing substrate types

\begin{tabular}{|c|c|c|c|c|c|}
\hline Source & SS & df & MS & $F$ & $\mathrm{p}$ \\
\hline Substrate & 32.229 & 4 & 8.057 & 18.48 & $<0.001$ \\
\hline Coralline cue: LR (present) vs. DR, DF, FS (absent) & 21.025 & 1 & 21.025 & 48.22 & $<0.001$ \\
\hline Structure: LR, DR (high) vs. DF, FS (low) & 14.807 & 1 & 14.807 & 33.97 & $<0.001$ \\
\hline Error & 8.721 & 20 & 0.436 & & \\
\hline
\end{tabular}

occurred on all 5 substrates. Selection varied significantly across substrate types after $3 \mathrm{~d}$, decreasing with a decline in structural complexity and loss of the live coralline cue (Fig. 3; Table 3). Settlement was highest on substrates with the live coralline cue present, and when comparing live vs. dead coralline surfaces respectively, settlement density was 3.3 times greater $\left(55.8 \pm 14.6\right.$ vs. $17.0 \pm 4.9$ larvae $\left.\mathrm{cm}^{-2}\right)$ on whole rhodoliths and 7 times greater $(24.2 \pm 4.7$ vs. $3.4 \pm 1.3$ larvae $\mathrm{cm}^{-2}$ ) on fragmented rhodoliths. Post hoc tests supported the findings that live coralline surfaces and higher structural complexity significantly enhanced settlement (contrast tests; Table 3).

Settlement of crested larvae occurred on all treatments of Lithophyllum margaritae in the laboratory growth experiment and ranged from an average $( \pm \mathrm{SE})$ high of $731 \pm 111$ total number of settlers on live, branching rhodolith material, to a low of $202 \pm 37$ on dead fragments (Fig. 4A). Settled larvae were generally evenly distributed over the settlement surfaces within each treatment, and no preference for microhabitats such as newly exposed portions of broken branches was apparent. Coralline cue and structural complexity both had separate and significant effects on settlement (Table 4). Settlement was highest on live rhodoliths with the live coralline cue and intact

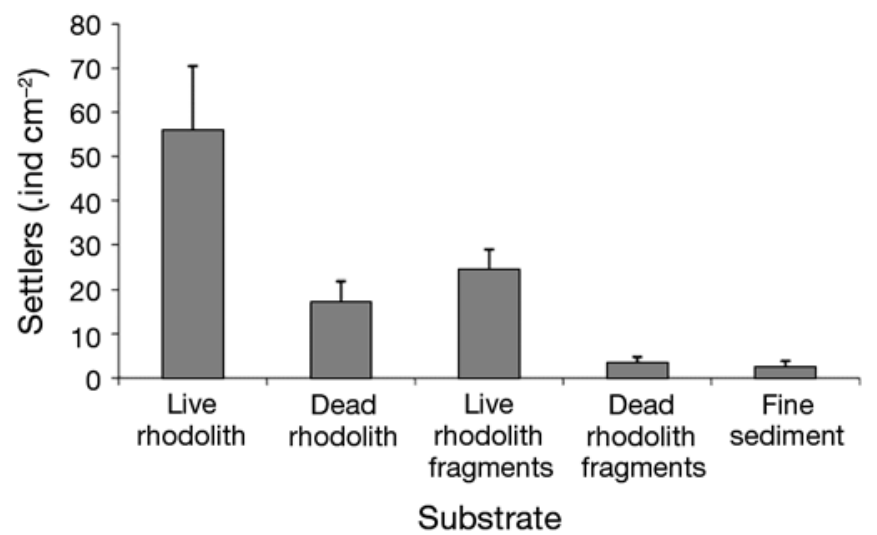

Fig. 3. Argopecten ventricosus. Laboratory settlement preferences of larval scallops relative to substrate treatments (Lithophyllum margaritae whole and fragmented rhodoliths and non-carbonate fine sediment). $\mathrm{n}=5$; error bars $=\mathrm{SE}$
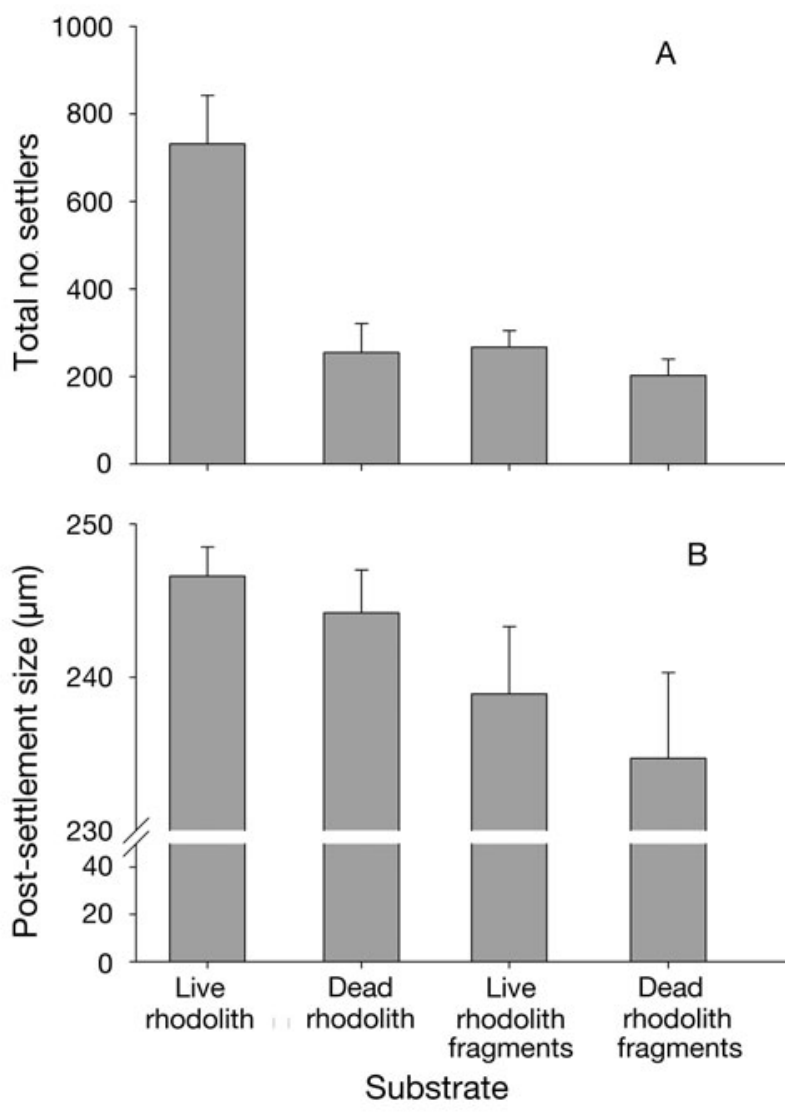

Fig. 4. Argopecten ventricosus. Mean \pm SE (A) total number of larval settlers and (B) post-settlement size relative to substrate type in a laboratory settlement and growth experiment

branching. Within comparable levels of structural complexity, settlement was higher in the presence of a live coralline cue, and within comparable levels of live coralline surface treatment (present vs. absent), settlement was higher in the presence of greater complexity.

\section{Effects of substrate on growth}

Individuals with post-settlement growth crests occurred on all treatments in the laboratory growth 
Table 4. Argopecten ventricosus. Effects of live coralline cue (present vs. absent) and rhodolith structural complexity (high vs. low) on the ln-transformed total number of settlers and post-settlement size (maximum shell depth in $\mu \mathrm{m}$ ) using a 2-way fixed factor ANOVA

\begin{tabular}{|lrrrrr|}
\hline Source & SS & df & MS & $F$ & $\mathrm{p}$ \\
\hline Total no. settlers & & & & & \\
Coralline cue & 1.974 & 1 & 1.974 & 13.281 & 0.003 \\
Structure & 1.409 & 1 & 1.409 & 9.479 & 0.011 \\
Cue $\times$ Structure & 0.635 & 1 & 0.635 & 4.269 & 0.061 \\
Error & 1.784 & 12 & 0.149 & & \\
& & & & & \\
Post-settlement size & & & & & \\
Coralline cue & 0.001 & 1 & 0.001 & 0.741 & 0.406 \\
Structure & 0.005 & 1 & 0.005 & 4.824 & 0.048 \\
Cue $\times$ Structure & 0.000 & 1 & 0.000 & 0.07 & 0.796 \\
Error & 0.013 & 12 & 0.001 & & \\
\hline
\end{tabular}

experiment and post-settlement size was higher on whole rhodolith treatments with intact structure (LR and $\mathrm{DR}_{\text {; Fig. }}$ BB) relative to fragmented treatments. There was a significant and positive effect of high vs. low structural complexity on post-settlement size for both live $(246.6 \pm 1.9$ vs. $238.9 \pm 4.4 \mu \mathrm{m})$ and dead $(244.2 \pm 2.8$ vs. $234.7 \pm 5.6 \mu \mathrm{m})$ coralline surfaces (Table 4). Overall, individuals were $~ 8.6 \mu \mathrm{m}$ larger on rhodoliths with intact branching structure. Within comparable levels of structural complexity, there was a positive yet non-significant effect of coralline cue on size with larger individuals found in the presence of the live coralline cue. A power analysis revealed that with a sample size of $\mathrm{n}=4$, there was insufficient power $(1-\beta=0.498)$ to capture a non-significant result for the importance of coralline cue.

\section{DISCUSSION}

This study provides the first examination of the proximal settlement factors contributing to the role that rhodolith beds may play as 'nursery grounds' for invertebrate species. We found that both settlement and early post-settlement growth are enhanced on rhodolith-derived substrates. In particular, we found that surface cues of living coralline surfaces and greater surface complexity were important in enhancing scallop larval settlement. Past studies have reported high juvenile scallop densities ( $\geq 18$ to $35 \mathrm{~mm}$ ) in rhodolith beds (Kamenos et al. 2004a) and attributed this to greater selection, attachment and juvenile growth (Kamenos et al. 2004b, c). The high densities of scallop settlers found on rhodolith derived substrates in this study demonstrates a link between the planktonic stage and enhanced early settlement that may contribute to the high densities of early juvenile stages and subsequent adult stages reported in other studies. Furthermore, enhanced early growth on rhodolithderived substrates provides a clear benefit to early life stages for detecting specific settlement cues.

\section{Effects of substrate on settlement}

Coralline algal surfaces enhance invertebrate larval settlement and this has been attributed to factors including growth form, surface chemistry, photosynthetic pigments, macroalgal epibionts, biofilms of diatoms or bacteria, and the presence of newly exposed surfaces through sloughing and breakage (Morse \& Morse 1984, Stoner et al. 1996, Daume et al. 1999a). While some invertebrates (e.g. abalone and coral spp.) demonstrate a high specificity for coralline algal-associated cues for settlement and metamorphosis (Morse \& Morse 1984, Raimondi \& Morse 2000), Argopecten ventricosus larvae do not require coralline surfaces for settlement. However, our results strongly suggest that features associated with live coralline surfaces (e.g. surface chemistry, proteins and/or mediation by microbial epibionts), regardless of structural integrity, attract scallop larvae and enhance larval settlement. A surface cue associated with live coralline algae that could contribute to enhanced settlement is an unidentified peptide mimic of the common neurotransmitter, $\gamma$-amino butyric acid (GABA). While GABA has been shown to induce larval settlement in gastropod species (Morse \& Morse 1984, Daume et al. 1999a), similar effects have not been demonstrated for bivalve species and this would require further investigation. There is also evidence that other red algal molecules may promote larval scallop metamorphoses: extracts of some non-coralline red algal species enhanced larval metamorphoses in the scallop Pecten maximus (Chevolot et al. 1991). The settlement responses onto live coralline surfaces in this study may be due to a complex synergy of cues that may include the coralline surfaces and surface epibionts.

A potential stimulus for enhanced scallop settlement on living rhodoliths is the presence of biofilms. Biofilms of diatoms and bacteria on various marine substrate surfaces, including live corallines, have also been shown to positively influence larval settlement for some invertebrates (Morse et al. 1988, Daume et al. 1999b, Huggett et al. 2006) including scallops (Parsons et al. 1993, Pearce \& Bourget 1996, Prescott et al. 2007, Leyton \& Riquelme 2008). Kreft et al. (2001) suggested that substrate texture is one of the determining factors in biofilm formation on surfaces in the marine environment. Rough surfaces present more surface area and a greater diversity of microhabitats than smooth 
substrates and thus may provide micro-successional mechanisms favorable to larval settlement (Bourget et al. 1994). It is unclear exactly what role biofilms play in scallop settlement, but it may be related to the transition from feeding with a ciliated velum to the gill filament of the benthic phase (Caddy 1969). This may serve as a mechanism by which complex rhodolith surfaces contribute to enhancing larval settlement and needs further examination.

One of the most obvious features of rhodolith beds is the high surface heterogeneity of rhodoliths relative to most soft-sediment substrates. Increased surface heterogeneity has long been recognized as an important factor enhancing larval settlement of many benthic invertebrates in addition to providing protection from predation and enhancing local availability of food resources (Crisp 1974, 1976, Brand et al. 1980). In contrast to Prescott et al. (2007), who found that substrate complexity alone did not attract Argopecten ventricosus scallop larvae, we found enhanced larval settlement on the more complex rhodolith surfaces. Our finding is similar to other settlement studies that found preferential scallop settlement on a wide range of substrates with enhanced structural complexity (Brand et al. 1980, Harvey et al. 1993, Pearce et al. 1996).

Higher settlement onto complex substrates may result from the increased probability of contact between key features of larvae and the substrate. For example, larval mussel attachment to complex substrates under moving water conditions is enhanced by the mucous thread produced by competent swimming larvae that increases the probability of substrate contact (Cáceres-Martínez et al. 1994). Competent swimming larvae of Argopecten ventricosus also have a mucous thread that may increase the frequency of contact with the complex substrates. In addition, postcontact discrimination of fine scale differences in substrate complexity has been well documented in bivalve larvae. Some scallop larvae can differentiate between rocks and large fragments vs. sandy sediments (Pearce \& Scheibling 1991), and others have shown that larvae have a strong preference for larger grain sediments (Baqueiro-Cardenas et al. 1981, Thouzeau et al. 1991). Enhanced substrate contact combined with a preference for heterogeneous substrates could explain the higher settlement rates we found on rhodolith substrates. It could also explain the significant difference in settlement patterns between locations measured in the field experiment. Higher settlement on substrates introduced into the sand flat relative to those in the rhodolith bed may have been from simple differences in larval supply. Alternatively, larvae over sand flats may contact fewer heterogeneous substrates, thereby locally increasing larval supply to experimental treatments.

\section{Effects of substrate cues on larval growth}

Few studies link the cues important for driving settlement choices to increased post-settlement growth. Increased early growth enables newly settled larvae to quickly transition from vulnerable early life history stages. Scallop larvae that settled onto rhodoliths with intact structure in this study, regardless of whether the coralline surface was live or dead, experienced higher post-settlement growth as revealed by increased size. Our results strongly suggest that maintaining beds of rhodoliths with intact structure could contribute to scallop production through enhanced growth. In addition, the trend of larger post-settlement individuals on live coralline substrates likewise suggests that maintaining living rhodoliths could also enhance scallop production through increased growth at small life stages. Further investigation with greater replication could strengthen this argument.

\section{Conservation and management implications}

Our studies indicate that the combination of physical and biological cues presented by biogenic rhodolith habitat act to enhance settlement, growth and potentially survival of larval scallops. It is likely that rhodoliths play a similar role for other benthic species. Our study examined the role of Lithophyllum margaritae rhodoliths at the scale of individual rhodoliths. The broader scale implications of our results can be better considered by scaling up to the level of rhodolith beds. Within a bed, live rhodolith densities are variable but can range from a few hundred up to 5000 to 10000 thalli $\mathrm{m}^{-2}$ (Cabioch 1969, Bosence 1976, Steller et al. 2003), and can cover $10 \mathrm{~s}$ of $\mathrm{km}^{2}$. At these extents and densities, beds likely act to accumulate larvae of many species, resulting in much higher local biodiversity compared to adjacent sandy bottoms (Keegan 1974).

Many commercially harvested species are associated with rhodolith beds. In Europe, there is a large-scale fishery for the scallop species Pecten maximus, which often is associated with Scottish maerl beds (HallSpencer \& Moore 2000a). In Pacific Mexico, commercially important scallops (Argopecten ventricosus, Pecten vogdesi and Lyropecten subnodosus) and other bivalves (Pinna rugosa and Atrina maura) are associated with rhodolith beds (Steller et al. 2003). Fisheries operations, however, can seriously disrupt coralline algal beds. For example, dredging operations for scallops in the Scottish maerl beds results in the breakage and burial of rhodoliths (Hall-Spencer 1999, HallSpencer \& Moore 2000a), which, when combined with decades of mining maerl for carbonates used in agriculture, (Blunden et al. 1975) has resulted in wide- 
spread destruction. Extreme disturbance can result in reduction of thallus density, size and complexity and ultimately transition to a low-diversity carbonate sand flat, increasing soft sediment suspension-feeders (Grall $\&$ Glemarec 1997) and the number of scavengers (HallSpencer \& Moore 2000a). In Mexican rhodolith beds, damage due to bivalve harvesting with hookah and dragged nets is more localized, but results in significant rhodolith damage through crushing and burial (D. Steller pers. obs.).

In addition to their potential direct role as nursery grounds, natural breakage and degradation of living individual rhodoliths produce large-grain calcareous sediment that serves to increase complexity within and directly adjacent to rhodolith beds. Thus, the maintenance of living rhodolith beds influences heterogeneous biogenic habitat production at 2 levels: the living bed itself and the production of complex soft bottoms over more extensive areas. Unfortunately, wide-spread damage to rhodoliths, combined with slow recovery times predicted from the slow rhodolith growth rates measured on a range of species worldwide (Blake \& Maggs 2004, Rivera et al. 2004, Steller et al. 2007), has resulted in significant global degradation of rhodolith biogenic habitat. Given the biodiversity associated with rhodolith beds and the likely importance of these for larval settlement, post-settlement growth, survival and reproduction of commercially important and other associated species - similar to the role of other biogenic habitats such as kelp beds and coral reefs - global conservation of rhodoliths is warranted.

Acknowledgements. The authors thank UC MEXUS (University of California Institute for Mexico and the United States), the American Academy of Underwater Sciences and the Earl and Ethel Meyers Oceanographic Trust whose support made this work possible, and the UABCS Universidad Autónoma de Baja California Sur Pichilingue laboratory facilities. Additionally, we thank J. Cortés-Salazar, S. Senyak, A. Hebshi, A. Marchesi, S. Wilson and R. Dunn for laboratory support, M. Edwards, E. Maloney, L. Garske, M. George, J. Negrey and other Baja California Sur Ecological Society members for diving support and R. Riosmena-Rodríguez, UABCS for coralline taxonomic identification. Thank you to P. T. Raimondi, M. S. Foster, D. Doak, J. Estes and D. A. Croll and the anonymous reviewers for constructive comments on the manuscript. Gracias a las familias Lucero y Cuevas por sus casas y amistad.

\section{LITERATURE CITED}

Abelson A, Denny M (1997) Settlement of marine organisms in flow. Annu Rev Ecol Syst 28:317-339

Baqueiro-Cardenas E, Masso-Rojas A, Pena-Ramirez I (1981) Análisis de una población sobreexplotada de la almeja catarina Argopecten circularis (Sowerby, 1835) de la Ensenada de La Paz, B.C.S., México. Cienc Pesq 1:57-65

Blake C, Maggs CA (2004) Comparative growth rates and internal banding periodicity of maerl species (Coralli- nales, Rhodophyta) from northern Europe. Phycologia 42: 606-612

Blunden G, Binns WW, Perks F (1975) Commercial collection and utilisation of maerl. Econ Bot 29:140-145

Bosence DWJ (1976) Ecological studies on two unattached coralline algae from western Ireland. Palaeontology 19: 365-395

Bosence DWJ (1979) Live and dead faunas from coralline algal gravels, Co. Galway. Palaeontology 22:449-478

Bosence DWJ (1983) The occurrence and ecology of recent rhodoliths: a review. In: Peryt TM (ed) Coated Grains. Springer Verlag, Berlin, p 225-242

Bourget E, Guise J, Daigle G (1994) Scales of substratum heterogeneity, structural complexity, and the early establishment of a marine epibenthic community. J Exp Mar Biol Ecol 181:31-51

Brand AR, Paul JD, Hoogesteger JN (1980) Spat settlement of the scallops Chlamys opercularis (L.) and Pecten maximus (L.) on artificial collectors. J Mar Biol Assoc 60: 379-390

Butman CA, Grassle JP, Webb CM (1988) Substrate choices made by marine larvae settling in still water and in a flume flow. Nature 333:771-773

Cabioch J (1969) Les fonds de maerl de la Baie de Morlaix et leur peuplement vegetal. Cah Biol Mar 9:139-161

Cáceres-Martínez J, Robledo JAF, Figueras A (1994) Settlement and post-larvae behaviour of Mytilus galloprovincialis: field and laboratory experiments. Mar Ecol Prog Ser 112:107-117

Caddy JF (1969) Development of mantle organs, feeding and locomotion in post-larval Macoma balthica (L.) (Lamellibranchiata). Can J Zool 47:609-617

Caley MJ, Carr MH, Hixon MA, Hughes TP, Jones GP, Menge BA (1996) Recruitment and the local dynamics of open marine populations. In: Fautin DG (ed) Annual review of ecology and systematics. Annual Reviews Inc., Palo Alto, CA, p 477-500

Chavez-Villalba J, Cáceres-Martínez C (1992) Scallop culture in the Northwest of Mexico. World Aquaculture 23(4): $20-25$

> Chevolot L, Cochard JC, Yvin JC (1991) Chemical induction of larval metamorphosis of Pecten maximus with a note on the nature of naturally occurring triggering substances. Mar Ecol Prog Ser 74:83-89

- Connell JH (1985) The consequences of variation in initial settlement vs. post-settlement mortality in rocky intertidal communities. J Exp Mar Biol Ecol 93:11-46

Connolly SR, Roughgarden J (1999) Theory of marine communities: competition, predation, and recruitment-dependent interaction strength. Ecol Monogr 69:277-296

Crisp DJ (1955) The behaviour of barnacle cyprids in relation to water movement over a surface. J Exp Biol 32:569-590

Crisp DJ (1974) Factors influencing the settlement of marine invertebrate larvae. In: Grant PT, Mackie AM (eds) Chemoreception in marine organisms. Academic Press, London, p 177-265

Crisp DJ (1976) Settlement responses of marine organisms. In: Newell RC (ed) Adaptation to the environment: essays on the physiology of marine animals. Butterworths, London, p 83-124

> Crisp DJ, Meadows PS (1963) Adsorbed layers: the stimulus to settlement in Cirripedes. Proc R Soc Lond B Biol Sci 158: 364-387

> Crisp DJ, Ritz DA (1973) Response of cirrepede larvae to light. I. Experiments in white light. Mar Biol 23:327-335

> Daume S, Brand-Gardner S, Woelkerling WJ (1999a) Settlement of abalone larvae (Haliotis laevigata Donovan) in 
response to non-geniculate coralline red algae (Corallinales, Rhodophyta). J Exp Mar Biol Ecol 234:125-143

Daume S, Brand-Gardner S, Woelkerling WJ (1999b) Preferential settlement of abalone larvae: diatom films vs. nongeniculate coralline red algae. Aquaculture 174:243-254

Felix Pico EF (1991) Fisheries and aquaculture: Mexico. In: Shumway SE (ed) Scallops: biology, ecology and aquaculture. Elsevier Science Publishers, Amsterdam, p 943-977

Felix-Pico E, Tripp-Quezeda A, Castro-Ortiz J, SerranoCasillas G and others (1997) Repopulation and culture of the Pacific Calico scallops in Bahia Concepcion, Baja California Sur, Mexico. Aquacult Int 5:551-563

Foster MS (2001) Rhodoliths: between rocks and soft places. J Phycol 37:659-667

Gee JM (1965) Chemical stimulation of settlement in larvae of Spirorbis rupestris (Serpulidae). Anim Behav 13:181-186

Grall J, Glemarec M (1997) Biodiversite des fonds de maerl en Bretagne: approache fonctionnelle et impacts anthropogeniques. Vie Milieu 47:339-349

Grall J, Le Loc'h F, Guyonnet B, Riera P (2006) Community structure and food web based on stable isotopes (DELTA15N and DELTA13C) analysis of a North Eastern Atlantic maerl bed. Mar Ecol Prog Ser 338:1-15

Hadfield MG (1986) Settlement and recruitment of marine invertebrates: a perspective and some proposals. Bull Mar Sci 39:418-425

Hall-Spencer JM (1999) Effects of towed demersal fishing gear on biogenic sediments: a 5-year study. In: Giovanardi O (ed) Impact of trawl fishing on benthic communities. ICRAM, Rome, p 9-20

Hall-Spencer JM, Moore PG (2000a) Impact of scallop dredging on maerl grounds. In: Kaiser MJ, DeGroot SJ (eds) Effects of fishing on non-target species and habitats: biological, conservation and socio-economic issues. Blackwell Scientific, Oxford, p 105-117

Hall-Spencer JM, Moore PG (2000b) Scallop dredging has profound, long-term impacts on maerl habitats. ICES J Mar Sci 57:1407-1415

> Harvey M, Bourget E (1997) Recruitment of marine invertebrates onto arborescent epibenthic structures: active and passive processes acting at different spatial scales. Mar Ecol Prog Ser 153:203-215

> Harvey M, Bourget E, Miron G (1993) Settlement of Iceland scallop Chlamys islandica spat in response to hydroids and filamentous red algae: field observations and laboratory experiments. Mar Ecol Prog Ser 99:283-292

- Hay ME (1996) Marine chemical ecology: What's known and what's next? J Exp Mar Biol Ecol 200:103-134

Hily C, Potin P, Floc'h JY (1992) Structure of subtidal algal assemblages on soft-bottom sediments: fauna/flora interactions and role of disturbances in the Bay of Brest, France. Mar Ecol Prog Ser 85:115-130

> Huggett MJ, Williamson JE, de Nys R, Kjelleberg S, Steinberg PD (2006) Larval settlement of the common Australian sea urchin Heliocidaris erythrogramma in response to bacteria from the surface of coralline algae. Oecologia 149: $604-619$

Kamenos NA, Moore PG, Hall-Spencer JM (2004a) Nurseryarea function of maerl grounds for juvenile queen scallops Aequipecten opercularis and other invertebrates. Mar Ecol Prog Ser 274:183-189

Kamenos NA, Moore PG, Hall-Spencer JM (2004b) Attachment of the juvenile queen scallop (Aequipecten opercularis L.) to maerl in mesocosm conditions; juvenile habitat selection. J Exp Mar Biol Ecol 306:139-155

Kamenos NA, Moore PG, Hall-Spencer JM (2004c) Maerl grounds provide both refuge and high growth potential for juvenile queen scallops (Aequipecten opercularis L.). J Exp Mar Biol Ecol 313:241-254

Kamenos NA, Calosi P, Moore PG (2006) Substratummediated heart rate responses of an invertebrate to predation threat. Anim Behav 71:809-813

Keegan BF (1974) The macrofauna of maerl substrates on the west coast of Ireland. Cah Biol Mar IV:513-530

Keough MJ (1998) Responses of settling invertebrate larvae to the presence of established recruits. J Exp Mar Biol Ecol 231:1-19

> Keough MJ, Raimondi PT (1995) Responses of settling invertebrate larvae to bioorganic films: effects of different types of films. J Exp Mar Biol Ecol 185:235-253

Knight-Jones EW, Morgan E (1966) Responses of marine animals to changes in hydrostatic pressure. Oceanogr Mar Bio Annu Rev 4:267-299

Kreft JU, Picioreanu C, Wimpenny JWT, Van Loosdrecht MCM (2001) Individual based modeling of biofilms. Microbiology 147:2897-2912

> Le Tourneux F, Bourget E (1988) Importance of physical and biological settlement cues used at different spatial scales by the larvae of Semibalanus balanoides. Mar Biol 97: 57-66

Leyton YE, Riquelme CE (2008) Use of specific bacterialmicroalgal biofilms for improving the larval settlement of Argopecten purpuratus (Lamarck, 1819) on three types of artificial spat-collecting materials. Aquaculture 276:78-82

Maeda-Martinez AN, Reynoso-Granados T, MonsalvoSpencer P, Sicard MT and others (1997) Suspension culture of catarina scallop Argopecten ventricosus (= circularis) (Sowerby II, 1842) in Bahia Magdalena, Mexico, at different densities. Aquaculture 158:235-246

Maki JS, Rittschof D, Schmidt AR, Snyder AG, Mitchell R (1989) Factors controlling attachment of bryozoan larvae: a comparison of bacterial films and unfilmed surfaces. Biol Bull 177:295-302

Medina B, Guzman HM, Mair JM (2007) Failed recovery of a collapsed scallop (Argopecten ventricosus) fishery in Las Perlas Archipelago, Panama. J Shellfish Res 26:9-15

Miron G, Bourget E, Archambault P (1996) Scale of observation and distribution of adult conspecifics: their influence in assessing passive and active settlement mechanisms in the barnacle Balanus crenatus (Brugiere). J Exp Mar Biol Ecol 201:137-158

Morgan S (2001) Larval ecology of marine communities. In: Bertness MD, Gaines SD, Hay ME (eds) Marine community ecology. Sinauer Associates, Inc., Sunderland, MA, p 159-181

Morse ANC (1992) Role of algae in the recruitment of marine invertebrate larvae. In: John DM, Hawkins SJ, Price JH (eds) Plant-animal interactions in the marine-benthos. Clarendon Press, Oxford, p 385-403

Morse ANC, Morse DE (1984) Recruitment and metamorphosis of Haliotis larvae are induced by molecules uniquely available at the surfaces of crustose red algae. J Exp Mar Biol Ecol 75:191-215

> Morse DE, Hooker N, Morse ANC, Jensen RA (1988) Control of larval metamorphosis and recruitment in sympatric agariciid corals. J Exp Mar Biol Ecol 116:193-218

Parsons GJ, Dadswell MJ, Roff JC (1993) Influence of biofilm on settlement of sea scallop, Placopecten magellanicus (Gmelin, 1791), in Passamaquoddy Bay, New Brunswick, Canada. J Shellfish Res 12:279-283

> Pearce CM, Bourget E (1996) Settlement of larvae of the giant scallop, Placopecten magellanicus (Gmelin), on various artificial and natural substrata under hatchery-type conditions. Aquaculture 141:201-221 
Pearce CM, Scheibling RE (1990) Induction of metamorphosis of larvae of the green sea urchin, Strongylocentrotus droebachiensis, by coralline red algae. Biol Bull 179:304-311

Pearce CM, Scheibling RE (1991) Effect of macroalgae, microbial films, and conspecifics on the induction of metamorphosis of the green sea urchin Strongylocentrotus droebachiensis (Mueller). J Exp Mar Biol Ecol 147:147-162

Pearce CM, Gallager SM, Manuel JL, Manning DA, O'Dor RK, Bourget E (1996) Settlement of larvae of the giant scallop, Placopecten magellanicus, in 9-m deep mesocosms as a function of temperature stratification, depth, food, and substratum. Mar Biol 124:693-706

Prescott R, Koch V, Yingling C, Verdugo CR (2007) Settlement of Pacific calico scallop larvae: (Argopecten ventricosus, Sowerby II, 1842) on their predator, the black murex snail (Hexaplex nigritus, Philippi, 1845). J Shellfish Res 26: 1065-1070

Raimondi PT (1990) Patterns, mechanisms, consequences of variability in settlement and recruitment of an intertidal barnacle. Ecol Monogr 60:283-310

Raimondi PT, Morse ANC (2000) The consequences of complex larval behavior in a coral. Ecology 81:3193-3211

Riosmena-Rodríguez R, Woelkerling WJ, Foster MS (1999) Taxonomic reassessment of rhodolith-forming species of Lithophyllum (Corallinales, Rhodophyta) in the Gulf of California, Mexico. Phycologia 38:401-417

Rivera MG, Riosmena-Rodriguez R, Foster MS (2004) Age and growth of Lithothamnion muelleri (Corallinales, Rhodophyta) in the southwestern Gulf of California, Mexico. Cienc Mar 30:235-249

Rodriguez SR, Ojeda FP, Inestrosa NC (1993) Settlement of benthic marine invertebrates. Mar Ecol Prog Ser 97: 193-207

Ruiz-Martinez CA, Cáceras-Martínez C (1991) Experimental spat collection of scallops, Argopecten ventricosus (Sowerby 1985) auct. and Pecten vogdesi Arnold 1906, on a filament substrate in Falsa Bay, B.C.S., Mexico. In: Shumway SE, Sandifer PA (eds) An international compendium of scallop biology. World Aquaculture Society, Baton Rouge, LA, p 21-27

Steinberg PD, de Nys R (2002) Chemical mediation of colonization of seaweed surfaces. J Phycol 38:621-629

Steller DL, Foster MS (1995) Environmental factors influencing distribution and morphology of rhodoliths in Bahía Concepción, B.C.S., Mexico. J Exp Mar Biol Ecol 194: 201-212

Steller DL, Riosmena-Rodriguez R, Foster MS, Roberts CA (2003) Rhodolith bed diversity in the Gulf of California: the importance of rhodolith structure and consequences of disturbance. Aquat Conserv: Mar Freshwat Ecosyst 13:S5-S20

Editorial responsibility: Steven Morgan,

Bodega Bay, California, USA
Steller DL, Hernandez-Ayon J, Riosmena-Rodriguez R, Cabello-Pasini A (2007) Effect of temperature on photosynthesis, growth and calcification rates of the free-living coralline alga Lithophyllum margaritae. Cienc Mar 33: $441-456$

Stoner AW, Ray M, Glazer RA, McCarthy KJ (1996) Metamorphic responses to natural substrata in a gastropod larva: decisions related to postlarval growth and habitat preference. J Exp Mar Biol Ecol 205:229-243

Thorson G (1966) Some factors influencing the recruitment and establishment of marine benthic communities. Neth J Sea Res 3:267-293

Thouzeau G (1991) Experimental collection of postlarvae of Pecten maximus (L.) and other benthic macrofaunal species in the Bay of Saint-Brieuc, France: I. Settlement patterns and biotic interactions among the species collected. J Exp Mar Biol Ecol 148:159-180

Thouzeau G, Robert G, Smith SJ (1991) Spatial variability in distribution and growth of juvenile and adult sea scallops Placopecten magellanicus (Gmelin) on eastern Georges Bank (Northwest Atlantic). Mar Ecol Prog Ser 74: 205-218

Underwood AJ, Denley EJ (1984) Paradigms, explanations and generalizations in models for the structure of intertidal communities on rocky shores. In: Strong DR, Simberloff D, Abele LG, Thistle A (eds) Ecological communities: conceptual issues and the evidence. Princeton University Press, Princeton, NJ, p 151-180

Underwood AJ, Keough MJ (2000) Supply-side ecology: the nature and consequences of variations in recruitment of intertidal organisms. In: Bertness MD, Gaines SD, Hay ME (eds) Marine community ecology. Sinauer, Sunderland, MD

Uriarte I, Rupp G, Abarca A (2002) Producción de juveniles de pectinidos iberoamericanos en condiciones controladas. In: Maeda-Martínez A (ed) Los moluscos pectínidos de Iberoamérica: ciencia y acuicultura. Editorial LIMUSA, Mexico, p 147-171

Villalejo-Fuerte M (1993) El ciclo reproductivo de la almeja catarina Argopecten circularis Sowerby, 1835, en relacion con la temperatura y el fotoperiodo en Bahía Concepción, B.C.S. Mexico. Cienc Mar 19:181-202

> Walters LJ, Hadfield MG, Smith CM (1996) Waterbourne chemical compounds in tropical macroalgae: positive and negative cues for larval settlement. Mar Biol 126:383-393

- Woodin SA, Lindsay SM, Wethey DS (1995) Process-specific recruitment cues in marine sedimentary systems. Biol Bull 189:49-58

Young CM (1990) Larval ecology of marine invertebrates a sesquicentennial history. Ophelia 32:1-48

Submitted: February 16, 2009; Accepted: August 6, 2009 Proofs received from author(s): November 19, 2009 